\title{
Hoge Raad vs. A-G IJzerman: Is de Bedrijfsopvolgingsregeling in de Successiewet 1956 in Strijd met het Gelijkheidsbeginsel?
}

\section{Chantelle Senden}

De bedrijfsopvolgingsregeling in de Successiewet 1956 (SW) voorziet in een vrijstelling voor ondernemingsvermogen. De SW bevat echter geen soortgelijke vrijstelling voor particulier vermogen. Is dit in strijd met het gelijkheidsbeginsel? De Rechtbank Breda besliste op 13 juli 2012 dat de bedrijfsopvolgingsregeling in strijd is met het gelijkheidsbeginsel. Ten gevolge van de vele bezwaren naar aanleiding van deze uitspraak is vervolgens het massaal bezwaar als bedoeld in artikel 25a AWR toegepast. De Hoge Raad heeft in het kader van dit massaal bezwaar proefprocedures gevoerd, waarbij hij heeft beslist dat de bedrijfsopvolgingsregeling niet in strijd is met het gelijkheidsbeginsel. Advocaat-Generaal (A-G) IJzerman heeft in zijn conclusies bij deze beslissing van de Hoge Raad echter geadviseerd dat de bedrijfsopvolgingsregeling in strijd is met het gelijkheidsbeginsel. Wie heeft 'gelijk'? Is de bedrijfsopvolgingsregeling in strijd met het gelijkheidsbeginsel of niet?

\section{$1 \quad$ Inleiding}

De bedrijfsopvolgingsregeling in de Successiewet 1956 (SW) voorziet in een vrijstelling voor ondernemingsvermogen. De SW bevat echter geen soortgelijke vrijstelling voor particulier vermogen. Is dit in strijd met het gelijkheidsbeginsel? De Rechtbank Breda besliste op 13 juli 2012 dat de bedrijfsopvolgingsregeling in strijd is met het gelijkheidsbeginsel. ${ }^{1}$ Ten gevolge van de vele bezwaren naar aanleiding van deze uitspraak is

1 Rechtbank Breda, 13 juli 2012, nr. 11/5509, V-N 2012/43.20. 
vervolgens het massaal bezwaar als bedoeld in artikel 25a AWR toegepast. De Hoge Raad heeft in het kader van dit massaal bezwaar proefprocedures gevoerd, waarbij hij heeft beslist dat de bedrijfsopvolgingsregeling niet in strijd is met het gelijkheidsbeginsel. Advocaat-Generaal (A-G) IJzerman heeft in zijn conclusies bij deze beslissing van de Hoge Raad echter geadviseerd dat de bedrijfsopvolgingsregeling in strijd is met het gelijkheidsbeginsel. Wie heeft 'gelijk'? Is de bedrijfsopvolgingsregeling in strijd met het gelijkheidsbeginsel of niet?

In dit artikel zal systematisch worden uitgezocht of de bedrijfsopvolgingsregeling in strijd is met het gelijkheidsbeginsel. Daartoe zal voor een beter inzicht eerst de bedrijfsopvolgingsregeling worden besproken (paragraaf 2). Daarna zal worden bekeken aan welk gelijkheidsbeginsel de bedrijfsopvolgingsregeling kan en mag worden getoetst (paragraaf 3 ). Gaat het hierbij om het gelijkheidsbeginsel dat is verankerd in de nationale wet of om het gelijkheidsbeginsel dat in internationale verdragen wordt genoemd? $\mathrm{Na}$ een bespreking van de hierboven genoemde proefprocedures van de Hoge Raad (paragraaf 4), zal een toetsing van de bedrijfsopvolgingsregeling aan het gelijkheidsbeginsel volgen (paragraaf 5 ). Tot slot worden in dit artikel nog verschillende opvattingen met betrekking tot dit onderwerp besproken (paragraaf 6 ) en wordt afgesloten met een conclusie (paragraaf 7).

\section{De Bedrijfsopvolgingsregeling in de $\mathrm{SW}$}

\subsection{Inleiding}

In deze paragraaf wordt ingegaan op de bedrijfsopvolgingsregeling. Om een goed inzicht te krijgen in de regeling wordt eerst de geschiedenis van de regeling besproken (paragraaf 2.2), waarna in zal worden gegaan op de huidige regeling (paragraaf 2.3). Ook zal worden stilgestaan bij het doel van de bedrijfsopvolgingsregeling (paragraaf 2.4).

\subsection{De geschiedenis van de bedrijfsopvolgingsregeling}

Vóór 1 januari 2002 was de bedrijfsopvolgingsregeling opgenomen in de Invorderingswet 1990 (IW). Die bedrijfsopvolgingsregeling bestond uit 
een kwijtschelding en een betalingsregeling. Ten eerste gold een volledige kwijtschelding van de erf- en schenkbelasting die kon worden toegerekend aan quota, vergunningen, concessies en andere dispensaties van publiekrechtelijke aard. Daarnaast gold een kwijtschelding van 25 procent van de erf- en schenkbelasting die kon worden toegerekend aan het overige verkregen ondernemingsvermogen. Deze kwijtscheldingsfaciliteiten konden materieel worden gezien als een vrijstelling van erf- en schenkbelasting. In aanvulling op deze kwijtscheldingsfaciliteiten, bestond een betalingsregeling op grond waarvan het deel van de erf- en schenkbelasting dat niet onder de kwijtscheldingsfaciliteiten viel in tien jaarlijkse termijnen renteloos kon worden betaald. Voorwaarde voor toepassing van de betalingsregeling was dat niet genoeg liquide of relatief eenvoudig te gelde te maken privé-vermogen was verkregen om de resterende erf- en schenkbelasting te voldoen. ${ }^{2}$

$\mathrm{Na}$ het rapport-Moltmaker ${ }^{3}$ van de door de staatssecretaris van Financiën ingestelde werkgroep modernisering successiewetgeving, werd de bedrijfsopvolgingsregeling per 1 januari 2002 overgeheveld naar de SW. De kwijtscheldingsfaciliteiten hadden plaats gemaakt voor vrijstellingen van erf- en schenkbelasting. Ten eerste gold een volledige vrijstelling voor het verschil tussen de liquidatiewaarde ${ }^{4}$ en de lagere going-concernwaarde ${ }^{5}$ van de verkregen onderneming. Daarnaast gold een vrijstelling van 30 procent voor de going-concernwaarde. In aanvulling op deze vrijstellingen bestond onder deze bedrijfsopvolgingsregeling een regeling voor uitstel van betaling van de erf- en schenkbelasting gedurende maximaal tien jaren voor het deel dat niet onder de vrijstellingen viel. Het verschil met de regeling voor uitstel van betaling van vóór 1 januari 2002 was dat invorderingsrente was verschuldigd. Bovendien moest niet meer in tien jaarlijkse termijnen worden betaald, maar na afloop van de tienjaars-termijn. ${ }^{6}$ Tot slot gold evenmin nog de voorwaarde van het niet voldoende aanwezig zijn van liquide middelen. Vervolgens is de vrijstelling van 30 procent voor de going-concernwaarde meermalen verruimd. Deze waarde

2 MvT, Kamerstukken II 1997/1998, 25 688, nr. 3, p. 8.

3 Rapport van de werkgroep modernisering successiewetgeving, De warme, de koude en de dode hand, 's-Gravenhage 13 maart 2000, par. 4.2.5 en 4.8.1.

4 De liquidatiewaarde is de waarde van een onderneming alsof deze wordt geliquideerd.

5 De going-concernwaarde is de waarde van een onderneming alsof deze wordt voortgezet.

6 MvT, Kamerstukken II 2001/2002, 28 015, nr. 3, p. 2-3. 
bedroeg 60 procent per 1 januari 2005 en 75 procent per 1 januari 2007. ${ }^{7}$

Met ingang van 1 januari 2010 is de voormalige bedrijfsopvolgingsregeling herzien. Het doel van deze herziening was om de bedrijfsopvolgingsregeling eenvoudiger, toegankelijker en evenwichtiger te maken. Bovendien moest worden bewerkstelligd dat enkel reële bedrijfsoverdrachten werden gefaciliteerd en andere overdrachten niet. ${ }^{8}$

\subsection{De huidige bedrijfsopvolgingsregeling}

Met ingang van 1 januari 2010 is de bedrijfsopvolgingsregeling opgenomen in artikel $35 \mathrm{~b}$ tot en met artikel $35 \mathrm{f} \mathrm{SW} .{ }^{9}$ De faciliteiten zijn opgenomen in artikel 35b SW. Op grond van dit artikel bestaat een volledige vrijstelling in het geval dat het verkregen ondernemingsvermogen $€ 1.028 .132$ niet te boven gaat. Wanneer het verkregen ondernemingsvermogen meer bedraagt dan $€$ 1.028.132, splitst artikel 35b SW de vrijstelling op in drie delen. Ten eerste geldt een volledige vrijstelling voor het verschil tussen de liquidatiewaarde en de lagere going-concernwaarde van de verkregen onderneming. Tevens geldt een volledige vrijstelling voor het verkregen ondernemingsvermogen dat $€ 1.028 .132$ niet te boven gaat. Ten slotte geldt een vrijstelling van 83 procent voor het ondernemingsvermogen dat meer bedraagt dan $€ 1$ 1.028.132. Naast deze vrijstellingen, behoort ook nog een regeling voor uitstel van betaling tot de bedrijfsopvolgingsfaciliteiten. ${ }^{10}$ Voor het deel dat niet onder de vrijstellingen valt, geldt gedurende maximaal tien jaren een regeling voor uitstel van betaling van de erf- en schenkbelasting.

Artikel $35 c$ tot en met artikel $35 f$ SW geven nadere regels met betrekking tot de bedrijfsopvolgingsfaciliteiten. De algemene definitie van een bedrijfsopvolging is gegeven in artikel 35b, vijfde lid, SW: "een verkrijging van ondernemingsvermogen van een erflater of schenker die voldoet aan de bezitstermijn, mits de verkrijger gedurende vijf jaren voldoet aan het voortzettingsvereiste." Deze definitie wordt nader uitgewerkt in artikel 35c tot en met artikel 35e SW. Artikel 35c SW geeft aan wat onder ondernemingsvermogen wordt verstaan, artikel 35d SW wat met de bezitstermijn wordt bedoeld en artikel $35 \mathrm{e} \mathrm{SW}$ wat het

7 Kamerstukken II 2004/2005, 29 767, nr. 58, p. 3-4.

8 MvT, Kamerstukken II 2008/2009, 31 930, nr. 3, p. 4-5.

9 Wet van 17 december 2009 (Stb. 2009, 564).

10 Artikel 35b, tweede lid, SW jo. artikel 25, twaalfde lid, IW. 
voortzettingsvereiste inhoudt. Ten slotte geeft artikel $35 \mathrm{f} \mathrm{SW}$ nadere regels met betrekking tot de verdeling van een nalatenschap en een huwelijksgoederengemeenschap.

\subsection{Het doel van de bedrijfsopvolgingsregeling}

Het doel van de bedrijfsopvolgingsregeling is zowel voor de regeling van vóór 2002 als voor de regeling tussen 2002 en 2010 en de regeling na 2010 onveranderd gebleven. Het betalen van erf- en schenkbelasting kan zorgen voor financiële problemen die de continuïteit van de onderneming zouden kunnen aantasten. Maar het is onwenselijk dat fiscale belemmeringen bedrijfsopvolging moeilijk of zelfs onmogelijk maken. Door middel van de bedrijfsopvolgingsregeling wilde de staatssecretaris van Financiën een bijdrage leveren aan de continuïteit van (familie-)ondernemingen door de druk van de erf- en schenkbelasting ten gevolge van de overgang van de onderneming te verminderen. ${ }^{11}$

\section{Het Gelijkheidsbeginsel en de Bedrijfsopvolgingsregeling}

\subsection{Inleiding}

Centraal in dit artikel staat de vraag of de bedrijfsopvolgingsregeling in strijd is met het gelijkheidsbeginsel. Om deze vraag te beantwoorden, zal moeten worden getoetst aan het gelijkheidsbeginsel. Maar het gelijkheidsbeginsel is zowel nationaal geregeld (paragraaf 3.2) als neergelegd in internationale verdragen (paragraaf 3.3). Aan welk gelijkheidsbeginsel moet de bedrijfsopvolgingsregeling worden getoetst en hoe vindt deze toetsing plaats? (paragraaf 3.4)

\subsection{Het nationaal geregelde gelijkheidsbeginsel}

Het gelijkheidsbeginsel is verankerd in artikel 1 Grondwet (Gw): "Allen die zich in Nederland bevinden, worden in gelijke gevallen gelijk behandeld. Discriminatie wegens godsdienst, levensovertuiging, politieke gezindheid, ras, geslacht of op welke grond dan ook, is niet toegestaan." Volgens artikel 120 Gw mag de rechter wetten en verdragen echter niet toetsen aan de Grondwet. De rechter mag dus

11 MvT, Kamerstukken II 1997/1998, 25 688, nr. 3, p. 8. 
niet toetsen of de in de SW neergelegde bedrijfsopvolgingsregeling in strijd is met het gelijkheidsbeginsel uit artikel $1 \mathrm{Gw}$.

Het gelijkheidsbeginsel is echter ook neergelegd in internationale verdragen, welke misschien een uitkomst bieden voor de toetsing van de bedrijfsopvolgingsregeling (zie paragraaf 3.3 hierna). Op grond van artikel 93 en $94 \mathrm{Gw}$ kunnen wettelijke voorschriften namelijk getoetst worden aan internationale verdragen.

\subsection{Het gelijkheidsbeginsel neergelegd in internationale verdragen}

Het gelijkheidsbeginsel is neergelegd in twee internationale verdragen, namelijk in het Internationaal Verdrag inzake Burgerrechten en Politieke Rechten (IVBPR) en in het Europees Verdrag voor de Rechten van de Mens (EVRM). In beide verdragen zijn fundamentele mensenrechten neergelegd.

Het gelijkheidsbeginsel dat is verankerd in artikel 26 IVBPR luidt: "Allen zijn gelijk voor de wet en hebben zonder discriminatie aanspraak op gelijke bescherming door de wet. In dit verband verbiedt de wet discriminatie van welke aard ook en garandeert een ieder gelijke en doelmatige bescherming tegen discriminatie op welke grond ook, zoals ras, huidskleur, geslacht, taal, godsdienst, politieke of andere overtuiging, nationale of maatschappelijke afkomst, eigendom, geboorte of andere status." Het gelijkheidsbeginsel dat is verankerd in artikel 14 EVRM is vrijwel gelijkluidend.

De staten die partij zijn bij het IVBPR en het EVRM dienen de fundamentele mensenrechten die daarin zijn neergelegd te waarborgen. Nederland is partij bij beide verdragen en dient ook de mensenrechten die daarin zijn neergelegd te waarborgen. Aangezien het gelijkheidsbeginsel is verankerd in zowel artikel 26 IVBPR als in artikel 14 EVRM is de rechter bevoegd de bedrijfsopvolgingsregeling hieraan te toetsen.

\subsection{De manier van toetsing}

Hiervoor is geconcludeerd dat de bedrijfsopvolgingsregeling getoetst kan worden aan het gelijkheidsbeginsel dat is neergelegd in artikel 26 IVBPR en artikel 14 EVRM. Het Europese Hof voor de Rechten van de Mens (EHRM) heeft in jurisprudentie bepaald aan de hand van welk 
toetsingskader dit moet plaatsvinden. ${ }^{12}$ De toetsing aan het gelijkheidsbeginsel dient plaats te vinden aan de hand van de volgende stappen:

1 Is er sprake van een ongelijke behandeling van gelijke gevallen?

2 Is er een objectieve en redelijke rechtvaardiging voor de ongelijke behandeling?

3 Is de maatregel proportioneel?

Wel dient rekening gehouden te worden met het feit dat de wetgever een ruime beoordelingsvrijheid heeft. ${ }^{13}$ Dit houdt in dat het oordeel van de wetgever dient te worden geëerbiedigd, tenzij dat van redelijke grond is ontbloot. ${ }^{14}$ In de proefprocedures die besproken worden in paragraaf 4 zal dit toetsingskader herkend worden en bij de toetsing aan het gelijkheidsbeginsel in paragraaf 5 zal de toetsing plaatvinden aan de hand van dit toetsingskader.

\section{De Proefprocedures}

\subsection{Inleiding}

De Rechtbank Breda besliste op 13 juli 2012 dat de bedrijfsopvolgingsregeling in strijd is met het gelijkheidsbeginsel. Ten gevolge van de vele bezwaren naar aanleiding van deze uitspraak is vervolgens het massaal bezwaar als bedoeld in artikel 25a AWR toegepast. De Hoge Raad heeft in het kader van dit massaal bezwaar proefprocedures gevoerd, waarbij hij heeft beslist dat de bedrijfsopvolgingsregeling niet in strijd is met het gelijkheidsbeginsel. A-G IJzerman heeft in zijn conclusies bij deze beslissing van de Hoge Raad echter geadviseerd dat de bedrijfsopvolgingsregeling in strijd is met het gelijkheidsbeginsel.

In deze paragraaf wordt allereerst de uitspraak van de Rechtbank Breda van 13 juli 2012 besproken (paragraaf 4.2). Vervolgens wordt kort ingegaan op de aanwijzing als massaal bezwaar (paragraaf 4.3). Daarna wordt de opvatting van de A-G besproken (paragraaf 4.4), waarna het oordeel van de Hoge Raad aan bod komt (paragraaf 4.5).

12 Bijv. EHRM 23 juli 1968 (Belgische taalzaken), Series A, nr. 6, 1 EHRR 252, par. 10.

13 Bijv. EHRM 28 november 1984 (Rasmussen), NJ 1986/4, r.o. 40 en EHRM 21 februari 1986 (James), NJCM-bulletin 1986, p. 546 e.v., r.o. 46.

14 HR 8 juli 2005, nr. 39 870, BNB 2005/310. 


\subsection{De Rechtbank Breda ${ }^{15}$}

De feiten

$X$ drijft een landbouwonderneming, waarvan het ondernemingsvermogen onder andere bestaat uit landbouwgronden, een boerderij met opstallen op een perceel van $5.000 \mathrm{~m}^{2}$ en landbouwmachines. In 2004 staakt X zijn landbouwonderneming en verpacht hij de gronden aan zijn zoon (belanghebbende). Wanneer $X$ in 2007 overlijdt, is belanghebbende enig erfgenaam. Hij verkrijgt het voormalige ondernemingsvermogen, de aan hem verpachte landbouwgronden, de boerderij en de landbouwmachines.

Belanghebbende is van mening dat hij een beroep kan doen op de bedrijfsopvolgingsregeling, omdat elke verkrijging krachtens erfrecht hetzelfde moet worden behandeld, ongeacht of sprake is van ondernemingsvermogen of van privévermogen.

Het oordeel van de rechtbank

De rechtbank stelt dat de verkrijgingen krachtens erfrecht van ondernemingsvermogen en van privévermogen voor de heffing van erfbelasting in beginsel zijn aan te merken als gelijke gevallen. Met de bedrijfsopvolgingsregeling worden deze gelijke gevallen ongelijk behandeld. De erfrechtelijke verkrijging van ondernemingsvermogen valt namelijk onder de bedrijfsopvolgingsregeling, terwijl de erfrechtelijke verkrijging van privévermogen hier niet onder valt. Het faciliteren van bedrijfsoverdrachten die anders niet zouden kunnen plaatsvinden bij een gebrek aan voldoende liquide middelen vormt in het algemeen een objectieve en redelijke rechtvaardiging voor een verschil in fiscale behandeling tussen de verkrijging van ondernemingsvermogen en de verkrijging van privévermogen. Dit verschil in fiscale behandeling moet echter wel proportioneel zijn, waarbij het feit dat de wetgever een ruime beoordelingsvrijheid heeft, moet worden meegenomen.

De rechtbank oordeelt dat het verschil in fiscale behandeling niet meer proportioneel is vanaf de verruiming van de bedrijfsopvolgingsregeling per 1 januari 2005. Er wordt namelijk geen onderscheid gemaakt tussen het wel of niet aanwezig zijn van liquiditeitsproblemen. Bovendien is het percentage aan ondernemingsvermogen dat wordt vrijgesteld zeer hoog. De rechtbank concludeert dat de wetgever met de verruiming van de bedrijfsopvolgingsregeling per 1 januari 2005 zijn ruime

15 Rechtbank Breda, 13 juli 2012, nr. 11/5509, V-N 2012/43.20. 
beoordelingsvrijheid heeft overschreden. Voor de hierdoor ontstane ongelijke behandeling van gelijke gevallen bestaat geen objectieve en redelijke rechtvaardiging. Volgens de rechtbank is de bedrijfsopvolgingsregeling met ingang van 1 januari 2005 in strijd met het gelijkheidsbeginsel.

\subsection{Massaal bezwaar bij de Hoge Raad}

Naar aanleiding van voorgenoemde uitspraak van de Rechtbank Breda dat de bedrijfsopvolgingsregeling in strijd is met het gelijkheidsbeginsel, is een groot aantal bezwaren ingediend bij de Belastingdienst. ${ }^{16}$ Aangezien deze bezwaren zich alle toespitsen op de rechtsvraag of de bedrijfsopvolgingsregeling in strijd is met het gelijkheidsbeginsel, heeft het Ministerie van Financiën besloten al deze bezwaren aan te wijzen als massaal bezwaar zoals bedoeld in artikel 25a AWR. ${ }^{17}$ Een vijftal zaken heeft nu als proefprocedures gediend en de andere bezwaarschriften zijn aangehouden. Zodra de Hoge Raad uitspraak heeft gedaan in de proefprocedures, zal deze uitspraak ook gelden voor de aangehouden bezwaarschriften middels een collectief uitspraak op bezwaar van de Belastingdienst.

Vier van deze proefprocedures betreffen een erflater die overlijdt en een aantal erfgenamen die privévermogen verkrijgen. De andere proefprocedure betreft een schenker die privévermogen schenkt aan haar zoon.

Op 30 september 2013 heeft de A-G conclusie genomen in deze vijf zaken die als proefprocedures dienen ${ }^{18}$ en op 22 november 2013 heeft de Hoge Raad uitspraak hierop gedaan. ${ }^{19}$

16 Brief Staatssecretaris van Financiën, 25 oktober 2012, nr. DGB/2012/6564M, V-N 2012/57.19.

17 Besluit van 23 oktober 2012, nr. BLKB2012/1665M.

18 HR (A-G) 30 september 2012, nr. 13/01154, V-N 2013/50.24.

19 HR 22 november 2013, nr. 13/01154, V-N 2013/59.21,

HR 22 november 2013, nr. 13/01160, V-N 2013/59.23.29,

HR 22 november 2013, nr. 13/01161, V-N 2013/59.23.30,

HR 22 november 2013, nr. 13/01622, V-N 2013/59.23.31,

HR 22 november 2013, nr. 13/02453, V-N 2013/59.23.32. 


\subsection{De opvatting van de $A-G^{20}$}

De A-G start met de constatering dat de verkrijgingen krachtens erf- en schenkbelasting van ondernemingsvermogen en van privévermogen in beginsel gelijke gevallen zijn. Met de bedrijfsopvolgingsregeling worden deze gelijke gevallen dus ongelijk behandeld. In het algemeen vormt het faciliteren van bedrijfsoverdrachten die anders niet zouden kunnen plaatsvinden bij een gebrek aan voldoende liquide middelen een objectieve en redelijke rechtvaardiging voor dit verschil in fiscale behandeling. Het verschil moet echter proportioneel zijn, waarbij het feit dat de wetgever een ruime beoordelingsvrijheid heeft, moet worden meegenomen.

De A-G meent - anders dan de rechtbank die de bedrijfsopvolgingsregeling vanaf de verruiming per 1 januari 2005 niet meer proportioneel acht - dat het verschil in fiscale behandeling niet meer proportioneel is vanaf de verruiming van de bedrijfsopvolgingsregeling per 1 januari 2010. Een vrijstelling van 75 procent was volgens de A-G nog proportioneel, maar de wettelijke verhoging naar meer dan 75 procent niet meer. Naar zijn mening is het gevolg hiervan dat rechtsherstel dienst plaats te vinden ten gunste van de gediscrimineerden, ofwel de verkrijgers van privévermogen die gebruik willen maken van de bedrijfsopvolgingsregeling. Dit rechtsherstel houdt in dat bij hen ook een vrijstelling wordt verleend naar de mate waarin in het jaar van verkrijging de bedrijfsopvolgingsregeling voorziet in een hogere wettelijke vrijstelling dan 75 procent.

\subsection{Het oordeel van de Hoge Raad ${ }^{21}$}

Ook de Hoge Raad haalt aan dat er in beginsel sprake is van gelijke gevallen en dat deze gelijke gevallen met de bedrijfsopvolgingsregeling ongelijk worden behandeld. Vervolgens gaat de Hoge Raad in op de vraag of een objectieve en redelijke rechtvaardiging voor een verschil in fiscale behandeling bestaat. Net als de rechtbank en de A-G is de Hoge Raad van mening dat een objectieve en redelijke rechtvaardiging voor

20 HR (A-G) 30 september 2012, nr. 13/01154, V-N 2013/50.24.

21 HR 22 november 2013, nr. 13/01154, V-N 2013/59.21, HR 22 november 2013, nr. 13/01160, V-N 2013/59.23.29, HR 22 november 2013, nr. 13/01161, V-N 2013/59.23.30, HR 22 november 2013, nr. 13/01622, V-N 2013/59.23.31, HR 22 november 2013, nr. 13/02453, V-N 2013/59.23.32. 
het verschil in fiscale behandeling aanwezig is, namelijk het waarborgen van de continuïteit van de onderneming.

De Hoge Raad oordeelt dat de bedrijfsopvolgingsregeling berust op een keuze van de fiscale wetgever waarvan niet kan worden gezegd dat zij evident van redelijke grond is ontbloot. De fiscale wetgever heeft zodoende met de bedrijfsopvolgingsregeling zijn ruime beoordelingsvrijheid niet overschreden. Volgens de Hoge Raad is de bedrijfsopvolgingsregeling niet in strijd met het gelijkheidsbeginsel.

$\mathrm{Na}$ dit oordeel van de Hoge Raad heeft de Belastingdienst naar aanleiding van het massaal bezwaar ten aanzien van de aangehouden bezwaarschriften op 4 december 2013 collectief uitspraak op bezwaar gedaan. ${ }^{22}$

\section{$5 \quad$ Toetsing aan het Gelijkheidsbeginsel}

\subsection{Inleiding}

In deze paragraaf wordt de bedrijfsopvolgingsregeling getoetst aan het gelijkheidsbeginsel. Deze toetsing zal plaatsvinden volgens het toetsingskader dat de Rechtbank Breda, de A-G en de Hoge Raad ook hebben gevolgd. Zoals besproken in paragraaf 3.4 heeft het EHRM dit toetsingskader in jurisprudentie uiteengezet:

1 Is er sprake van een ongelijke behandeling van gelijke gevallen? (paragraaf 5.2)

2 Is er een objectieve en redelijke rechtvaardiging voor de ongelijke behandeling? (paragraaf 5.3)

$3 \quad$ Is de maatregel proportioneel? (paragraaf 5.4)

$\mathrm{Na}$ het beantwoorden van deze drie vragen, kan geconcludeerd worden of de bedrijfsopvolgingsregeling in strijd is met het gelijkheidsbeginsel (paragraaf 5.5).

\subsection{Gelijke gevallen?}

Artikel 1, eerste lid, SW bepaalt dat erf- en schenkbelasting wordt geheven over de waarde van al wat krachtens erfrecht en schenking wordt verkregen. Het uitgangspunt van de SW is dat in beginsel de aard en hoedanigheid van hetgeen is verkregen voor de heffing van erf- en schenkbelasting niet relevant is. De SW heeft wel altijd vrijstellingen gekend, maar die vrijstellingen hebben nooit verband gehad met de aard van hetgeen werd verkregen. Die vrijstellingen hebben altijd

22 Staatscourant 2013, 34331. 
verband gehad met de verwantschap tussen erflater of schenker en verkrijger (zie artikel 32 en artikel 33 SW). De verkrijgingen krachtens erfrecht en schenking van ondernemingsvermogen en privévermogen zijn voor de heffing van erf- en schenkbelasting dus in beginsel aan te merken als gelijke gevallen. ${ }^{23}$ Het gaat namelijk in beide gevallen om een verkrijging krachtens erfrecht of schenking ingevolge artikel 1 , eerste lid, SW.

Door de bedrijfsopvolgingsregeling wordt dus inbreuk gemaakt op het uitgangspunt dat de verkrijgingen van ondernemingsvermogen en privévermogen gelijke gevallen zijn. De verkrijging van ondernemingsvermogen valt namelijk onder de bedrijfsopvolgingsregeling, terwijl de verkrijging van privévermogen hier niet onder valt.

\subsection{Objectieve en redelijke rechtvaardiging?}

De bedrijfsopvolgingsregeling is in het leven geroepen om bedrijfsoverdrachten die anders niet zouden kunnen plaatsvinden bij een gebrek aan voldoende liquide middelen, te faciliteren. De wetgever heeft hierbij zowel het oog gehad op het belang van onbelemmerde voortzetting van familiebedrijven binnen de kring van de ondernemer als op de stimulering van ondernemerschap. Ik ben van mening dat deze doelstelling een objectieve en redelijke rechtvaardiging voor het verschil in fiscale behandeling tussen de verkrijging van ondernemingsvermogen en de verkrijging van privévermogen vormt.

\subsection{Maatregel proportioneel?}

Zoals ik in paragraaf 3.4 heb beschreven, moet vooropgesteld worden dat de wetgever een ruime beoordelingsvrijheid heeft. Deze ruime beoordelingsvrijheid houdt in dat het oordeel van de wetgever dient te worden geëerbiedigd, tenzij dat van redelijke grond is ontbloot. Beoordeeld moet worden of het oordeel van de wetgever niet verder gaat dan voor het bereiken van de doelstelling die geldt als objectieve en redelijke rechtvaardiging nodig is.

Zoals besproken in paragraaf 2.2 is de bedrijfsopvolgingsregeling meermalen aangepast. $\mathrm{Bij}$ deze aanpassingen is het

23 Zie ook Brief van de Staatssecretaris van Financiën aan de Tweede Kamer van 12 juli 2004, nr. WDB 2004-420M B, Actiepunten uit rapportage 'Bedrijfsoverdracht, continuïteit door fiscaliteit', V-N 2004/37.7. 
vrijstellingspercentage telkens verhoogd. Deze verhogingen zijn ingevoerd naar aanleiding van verschillende rapporten en onderzoeken, uit welke bleek dat de bestaande bedrijfsopvolgingsregeling niet als toereikend werd ervaren. Zo is de verhoging van het vrijstellingspercentage van 25 naar 30 in 2002 gegrond op het rapportMoltmaker $^{24}$ van de door de staatssecretaris van Financiën ingestelde werkgroep modernisering successiewetgeving, de verhoging van het vrijstellingspercentage naar 50 in 2005 en vervolgens naar 75 in 2007 op het in opdracht van de minister van Financiën opgestelde rapport 'Bedrijfsoverdracht, continuïteit door fiscaliteit' ${ }^{25}$ en de verhoging van het vrijstellingspercentage naar 100 in 2010 op het onderzoek 'Civiele en fiscale bedrijfsopvolgingsfaciliteiten. Een praktijkonderzoek'. ${ }^{26}$ Het telkens verhogen van het vrijstellingspercentage steunt dus op onderzoek naar de noodzaak daarvan.

Maar door de rechterlijke instanties wordt niet getoetst of in de specifieke casussen sprake is van liquiditeitsproblemen bij de eventuele verschuldigdheid van erf- en schenkbelasting, hoewel het doel van de bedrijfsopvolgingsregeling is het faciliteren van bedrijfsoverdrachten die anders niet zouden kunnen plaatsvinden bij een gebrek aan voldoende liquide middelen. $\mathrm{Bij}$ de beoordeling van een zaak wordt geen onderscheid gemaakt tussen het wel of niet aanwezig zijn van liquiditeitsproblemen. Naar mijn mening is het vreemd dat de Hoge Raad gelijke gevallen ongelijk behandelt met de objectieve en redelijke rechtvaardiging van het doel van de regeling, terwijl dit doel vervolgens niet wordt getoetst. De bedrijfsopvolgingsregeling is dus van toepassing, ongeacht of sprake is van liquiditeitsproblemen bij eventuele verschuldigdheid van erf- en schenkbelasting. Het voorgaande leidt mijns inziens tot de conclusie dat de bedrijfsopvolgingsregeling van redelijke grond is ontbloot en dat de wetgever met de faciliteit de grenzen van zijn beoordelingsvrijheid heeft overschreden.

24 Rapport werkgroep modernisering successiewetgeving, De warme, de koude en de dode hand, 's-Gravenhage 13 maart 2000, par. 4.2.5 en 4.8.1.

25 Rapport Van Vroonhoven-Kok c.s., Bedrijfsoverdracht, continuïteit door fiscaliteit, Kamerstukken II, 2002/2003, 28 607, nr. 49.

26 Rapport W. Burgerhart, M.J. Hoogeveen en J.I.M. Egger, Civiele en fiscale bedrijfsopvolgingsfaciliteiten. Een praktijkonderzoek, maart 2009. 


\subsection{In strijd met gelijkheidsbeginsel?}

$\mathrm{Nu}$ ik in paragraaf 5.2 heb geconcludeerd dat sprake is van een ongelijke behandeling van gelijke gevallen, in paragraaf 5.3 dat sprake is van een objectieve en redelijke rechtvaardiging en tot slot in paragraaf 5.4 dat sprake is van een disproportionele maatregel, kan mijns inziens geconcludeerd worden dat de bedrijfsopvolgingsregeling in strijd is met het gelijkheidsbeginsel. Deze conclusie heeft te maken met het feit dat geen toetsing plaatsvindt met betrekking tot de aanwezigheid van liquiditeitsproblemen bij het eventueel verschuldigd zijn van erf- en schenkbelasting.

\section{Verschillende Opvattingen nader Beschouwd}

\subsection{Inleiding}

In deze paragraaf worden verschillende opvattingen over de eventuele strijdigheid van de bedrijfsopvolgingsregeling met het gelijkheidsbeginsel besproken. Eerst zullen opvattingen in de literatuur worden besproken (paragraaf 6.2), waarna zal worden ingegaan op de acties van de Stichting Meldpunt Collectief Onrecht (SMCO) (paragraaf 6.3) en de zienswijze van de staatssecretaris van Financiën (paragraaf 6.4). Tot slot zal een conclusie volgen over deze verschillende opvattingen (paragraaf 6.5).

\subsection{Opvattingen in de literatuur}

Burgerhart, Hoogeveen en Egger ${ }^{27}$

Het doel van de bedrijfsopvolgingsregeling is ervoor te zorgen dat de continuïteit van ondernemingen niet wordt bemoeilijkt of onmogelijk gemaakt door fiscale belemmeringen. Burgerhart, Hoogeveen en Egger geven aan dat de noodzaak van de bedrijfsopvolgingsregeling bij de invoering ervan niet is onderzocht. De auteurs vinden het opvallend dat de voortzettingsvereisten als grootste knelpunt voor de bedrijfsopvolging worden genoemd. Zij geven aan dat verwacht zou worden dat, als sprake is van een faciliteit voor een bedrijfsopvolging,

27 Rapport W. Burgerhart, M.J. Hoogeveen en J.I.M. Egger, Civiele en fiscale bedrijfsopvolgingsfaciliteiten. Een praktijkonderzoek, maart 2009. 
de eis dat de onderneming ook moet worden voortgezet geen probleem zou moeten zijn. ${ }^{28}$

Hoogeveen $^{29}$

Ook Hoogeveen merkt op dat de vrijstelling in het kader van de bedrijfsopvolgingsregeling is ingevoerd zonder dat onderzoek naar de eventuele liquiditeitsproblemen heeft plaatsgevonden. De enkele veronderstelling dat er liquiditeitsproblemen zijn, is voldoende aanleiding geweest voor de wetgever om in 1997 tot de invoering van de vrijstelling over te gaan. Dit vindt Hoogeveen vreemd, omdat vóór 1997 slechts in zeer beperkte mate gebruik werd gemaakt van de op dat moment bestaande betalingsregeling. De noodzaak van de faciliteit was dus verwaarloosbaar klein. ${ }^{30}$

Verder geeft Hoogeveen aan dat de verruimingen mede hebben plaatsgevonden naar aanleiding van 'signalen uit de praktijk' inhoudende dat de vrijstelling op dat moment niet groot genoeg was om de liquiditeitsproblemen weg te nemen. Deze signalen waren echter niet onderbouwd. $\mathrm{Zij}$ is van mening dat de wetgever meer zorgvuldigheid in acht had moeten nemen, zeker omdat het gaat om het verlenen van substantiële vrijstellingen. Uit de hele parlementaire geschiedenis kan worden afgeleid dat de invloed van belangenorganisaties en het bedrijfsleven om maatregelen te treffen voor de erf- en schenkbelasting groot is.

Hoogeveen komt tot de conclusie dat de gegeven motiveringen de invoering en verruiming van de vrijstelling niet legitimeren, omdat de noodzaak tot het treffen van een - ruime - vrijstelling op geen enkele manier aannemelijk is gemaakt. De wetgever heeft volgens haar dan ook in strijd gehandeld met het gelijkheidsbeginsel.

28 Rapport W. Burgerhart, M.J. Hoogeveen en J.I.M. Egger, Civiele en fiscale bedrijfsopvolgingsfaciliteiten. Een praktijkonderzoek, maart 2009, onderdeel 4.5.3.2.

29 M.J. Hoogeveen, De kwaliteit van de fiscale bedrijfsopvolgingswetgeving, Den Haag: Sdu 2011 .
30 M.J. Hoogeveen, De kwaliteit van de fiscale bedrijfsopvolgingswetgeving, Den Haag: Sdu 2011, par. 9.5.2. 
Van Vijfeijken ${ }^{31}$

Ook Van Vijfeijken geeft aan dat de stelling dat de verschuldigde erf- en schenkbelasting tot financiële problemen kan leiden die de continuïteit van de onderneming zouden kunnen aantasten op geen enkele wijze is onderbouwd. Dit blijkt noch uit de parlementaire geschiedenis noch uit empirisch onderzoek. Bovendien werd de faciliteit vóór de verhoging van het vrijstellingspercentage in 1997 slechts sporadisch gebruikt.

De conclusie van Van Vijfeijken luidt dat de rechtvaardigingsgrond voor de vrijstelling is komen te ontvallen, omdat geen systematisch onderzoek naar nut en noodzaak heeft plaatsgevonden. ${ }^{32}$

\subsection{Acties van de SMCO}

De SMCO maakt zich hard voor eenieder die is benadeeld door het handelen van (onder andere) de overheid. Bij de SMCO kunnen klachten worden ingediend en wanneer zij een aanleiding en mogelijkheid zien om een (collectief) juridisch gevolg aan een klacht te geven, zullen zij de benodigde (juridische) stappen ondernemen. ${ }^{33}$

Het voorgaande is ook gebeurd met betrekking tot de bedrijfsopvolgingsregeling. Naar aanleiding van de uitspraak van de Hoge Raad van 22 november 2013, waarin de Hoge Raad heeft geoordeeld dat de bedrijfsopvolgingsregeling niet in strijd is met het gelijkheidsbeginsel, zijn er veel klachten binnengekomen bij de SMCO.

Naar aanleiding van deze klachten heeft de SMCO op 22 januari 2014 namens honderden deelnemers een claim van meer dan 80 miljoen euro bij de Belastingdienst ingediend. De SMCO is het namelijk niet eens met de uitspraak van de Hoge Raad en stelt dat de wetgeving naar haar oordeel willekeurig tot stand is gekomen en dat dat niet is toegestaan. Met de claim hoopt de SMCO te bereiken dat de te veel betaalde belasting door privépersonen die vanaf 2005 een erfenis of schenking hebben ontvangen en daarover erf- of schenkbelasting hebben betaald, terug wordt betaald.

31 I.J.F.A. van Vijfeijken, 'De bedriifsopvolgingsfaciliteiten in het licht van het gelijkheidsbeginsel', in: Principieel belastingrecht: Liber Amoricum Richard Happé, Nijmegen: Wolf Legal Publishers 2011, p. 235-247.

32 I.J.F.A. van Vijfeijken, Wetsvoorstel 31930: gebrek aan visie, WFR 2009/1231.

33 < https://www.collectiefonrecht.nl/over-smco > 1 juni 2014 
Bovendien is de SMCO van plan een rechtszaak aan te spannen bij het EHRM. Op deze manier wil de SMCO de uitspraak van de Hoge Raad van 22 november 2013 nogmaals laten toetsen, opdat zekerheid ontstaat over de vraag of de bedrijfsopvolgingsregeling in strijd is met het gelijkheidsbeginsel.

\subsection{Zienswijze van de staatssecretaris van Financiën}

De (voormalige) staatssecretaris van Financiën Weekers heeft uitgesproken dat hij blij is met de uitspraak van de Hoge Raad. Dit is natuurlijk goed te begrijpen, omdat bij een andere uitspraak van de Hoge Raad veel belastinggeld terugbetaald zou moeten worden en dit in de toekomst zou leiden tot minder belastinginkomsten op het gebied van de SW.

In een brief aan de Tweede Kamer van 25 april 2014 gaat (huidige) staatssecretaris van Financiën Wiebes in op de arresten van de Hoge Raad van 22 november 2013 over de vraag of de bedrijfsopvolgingsregeling in strijd is met het gelijkheidsbeginsel. ${ }^{34} \mathrm{De}$ staatssecretaris geeft in deze brief aan dat hij het voornemen heeft om te onderzoeken of kan worden volstaan met een lager vrijstellingspercentage of met een betalingsregeling. Het voornemen tot dit onderzoek is mede geuit omdat uit gegevens van de Belastingdienst blijkt dat in 70 procent van de gevallen de te betalen erf- of schenkbelasting uit de nalatenschap betaald had kunnen worden.

$\mathrm{Na}$ een storm van kritiek van ondernemers op deze brief, laat het Ministerie van Financiën op 1 mei 2014 in het Financieel Dagblad echter weten het plan van staatssecretaris Wiebes weer in te trekken. ${ }^{35}$ Volgens het Ministerie van Financiën zijn er geen voornemens om de regeling nog deze kabinetsperiode aan te passen.

\subsection{Conclusie}

Ik heb geen literatuur kunnen vinden van auteurs die van mening zijn dat de bedrijfsopvolgingsregeling niet in strijd is met het gelijkheidsbeginsel. Als de acties van de SMCO daarbij opgeteld worden, kan geconcludeerd worden dat de Hoge Raad vrij alleen staat in zijn

34 Brief staatssecretaris van Financiën 25 april 2014, nr. AFP/2014/302. $35 \mathrm{~K}$. Broekhuizen \& J. Verbeek, 'Financiën trekt hogere erfbelasting weer in', FD 1 mei 2014. 
opvatting dat de bedrijfsopvolgingsregeling niet in strijd is met het gelijkheidsbeginsel. De Hoge Raad is echter wel de hoogste nationale rechter en zijn oordeel kan zeker niet zomaar aan de kant worden geschoven.

\section{$7 \quad$ Conclusie}

In dit artikel is systematisch uitgezocht of de bedrijfsopvolgingsregeling in strijd is met het gelijkheidsbeginsel. De vraag of de A-G of de Hoge Raad gelijk heeft, stond centraal in dit artikel. Na een bespreking van de bedrijfsopvolgingsregeling en de proefprocedures van de Hoge Raad, is een beter inzicht gekregen in de achtergrond van de proefprocedures bij de Hoge Raad.

$\mathrm{Bij}$ een toetsing van de bedrijfsopvolgingsregeling aan het gelijkheidsbeginsel moeten drie deelvragen worden beantwoord. Ten eerste de vraag of sprake is van een ongelijke behandeling van gelijke gevallen, daarnaast de vraag of een objectieve en redelijke rechtvaardiging voor deze ongelijke behandeling bestaat en tot slot de vraag of de maatregel proportioneel is. $\mathrm{Na}$ een bevestigende beantwoording van de eerste twee vragen, moet de derde vraag mijns inziens ontkennend worden beantwoord. De toepassing van de bedrijfsopvolgingsregeling hangt niet af van de aanwezigheid van liquiditeitsproblemen, maar veronderstelt dat deze liquiditeitsproblemen altijd aanwezig zijn. De bedrijfsopvolgingsregeling is daarom naar mijn mening van redelijke grond ontbloot en zodoende in strijd met het gelijkheidsbeginsel.

$\mathrm{Na}$ een blik op de literatuur en de acties van de SMCO, kan geconcludeerd worden dat de Hoge Raad vrij alleen staat in zijn opvatting dat de bedrijfsopvolgingsregeling niet in strijd is met het gelijkheidsbeginsel.

Mijn conclusie luidt dan ook dat de A-G gelijk heeft met betrekking tot zijn standpunt dat de bedrijfsopvolgingsregeling in strijd is met het gelijkheidsbeginsel en dat de Hoge Raad dientengevolge mijn inziens geen gelijk heeft. De Hoge Raad is echter wel de hoogste nationale rechter en zijn oordeel kan zeker niet zomaar aan de kant worden geschoven. Er zal nu afgewacht moeten worden wat de acties van de SMCO voor gevolgen zullen hebben en of de staatssecretaris van Financiën onderzoek zal gaan doen naar mogelijkheden zoals het volstaan van een lager vrijstellingspercentage of een betalingsregeling. 